\title{
A revision of the Late Ordovician marrellomorph arthropod Furca bohemica from Czech Republic
}

Štěpán Rak, Javier Ortega-Hernández, and David A. Legg

Acta Palaeontologica Polonica 58 (3), 2012: 615-628 doi: http://dx.doi.org/10.4202/app.2011.0038

The enigmatic marrellomorph arthropod Furca bohemica from the Upper Ordovician Letná Formation, is redescribed. Based on existing museum specimens and new material collected from the southern slope of Ostrý Hill (Beroun, Czech Republic), the morphology and taphonomy of $F$. bohemica is reappraised and expanded to produce a new anatomical interpretation. The previously distinct taxa $F$. pilosa and Furca sp., are synonymised with F. bohemica, the latter being represented by a tapho-series in which decay has obscured some of the diagnostic features. A cladistic analysis indicates close affinities between $F$. bohemica and the Hunsrïck Slate marrellomorph Mimetaster hexagonalis, together forming the Family Mimetasteridae, contrary to previous models for marrellomorph internal relationships. As with other representatives of the group, the overall anatomy of $F$. bohemica is consistent with a benthic, or possibly nektobenthic, mode of life. The depositional setting of the Letná Formation indicates that $F$. bohemica inhabited a shallow marine environment, distinguishing it palaeoecologically from all other known marrellomorphs, which have been reported from the continental shelf.

Key words: Arthropoda, Marrella, Mimetaster, shallow marine environment, Letná Formation, Barrandian, Ordovician, Ostrý Hill, Czech Republic.

Štěpán Rak [deiphon@geologist.com], Charles University, Institute of Geology and Palaeontology, Albertov 6, 128 43, Prague 2, Czech Republic; Javier Ortega-Hernández [jo314@esc.cam.ac.uk], Department of Earth Sciences, University of Cambridge, Downing Street, Cambridge CB2 3EQ, UK; David A. Legg [d.legg10@imperial.ac.uk], Department of Earth Sciences and Engineering, South Kensington Campus, Imperial College London, London SW7 2AZ, UK.

This is an open-access article distributed under the terms of the Creative Commons Attribution License (for details please see creativecommons.org), which permits unrestricted use, 
distribution, and reproduction in any medium, provided the original author and source are credited.

For Full text $(1,687.0 \mathrm{kB})$ 